\title{
The Changing Public Sector and the Contradiction of Economic Globalization
}

\author{
Nándor Sári \\ University of Pécs
}

\section{THE AIM OF THE PAPER}

This paper attempts to examine the impact that economic globalization has had on the public sector. In the past two decades, researchers have gradually turned their attention to international and global perspectives in their efforts to analyze the changing nature and patterns of welfare policies, development approaches and public sector systems. Accordingly, the aim of this study is to evaluate and discuss the characteristics of globalized economic processes in regard to policy-making and public service design.

\section{METHODOLOGY}

This study is based on mainstream literature review and secondary data analysis of the original data of OECD and World Bank report, with the aim of confirming the correlations between hyperglobalization - in other words, excessive economic liberalization associated with deep integration of markets and services - and public policy transformation. The study applies a research framework associated with public sector expenditure, economic openness and foreign trade patterns.

\section{MOST IMPORTANT RESULTS}

According to our results, the complex, contradictory impacts and processes of economic globalization contemporaneously have exacerbated socio-economic challenges, and have transformed the social dimensions of policy implementation. Furthermore, these multifaceted provocations have required active responses and solutions at international level. In addition, we identified that economic openness have positively correlated with public sector size - notwithstanding, the interpretation of the correlation may be influenced by several other factors, such as the "size" of nation-states.

\section{RECOMMENDATIONS}

The results suggest that improving public policy is indispensable for achieving good governance; and a proactive, adequate public sector might resolve the socio-economic issues that the market economy does not address. Therefore, a modernized public sector system, based on a multi-layered and multi-sectorial framework, could effectively reshape income distribution, combat poverty and counter threats related to globalization.

Keywords: economic liberalization, globalized processes, public sector, policy-making

Acknowledgements: The study has been funded by EFOP-3.6.3-VEKOP-16-2017-00007, "Young Researchers from Talented Students - Fostering Scientific Careers in Higher Education".

DOI: https://doi.org/10.15170/MM.2019.53.05.05 


\section{INTRODUCTION}

At the beginning of the 1980 s, the concept of globalization began to be used as a "graph" of global social and economic relations, which has prompted an outpouring of analyses, theoretical works - and a greater level of consciousness - aimed at assessing globalization during the 1990s. Thereafter, the academic debate on the accompanying economic and social impacts of globalization has considerably increased at the turn of the millennium. In parallel, based on the structural changes, the excessively multifaceted, interrelated challenges and an array of ambiguous processes brought about by internationalization, a strong demand has emerged for means to clearly understand the main objectives of globalization.

There is a long-established view that the decline of the public sector, as a result of globalization, is inevitable as long as capital outflow and efficiency losses remain caused by the sector itself. Indeed, in part because of an increasingly internationalized economic system, and thereafter, perhaps in part because of severe economic crises, the fiscal capacity of the public sector has shrunk significantly (Seelkopf et al. 2016). Nevertheless, the large public sector, despite the efficiency losses, is vastly required as a leveling factor for increased income risk. By the same token, globalization increases the risks of widespread income inequality, particularly among people with lower income, occupational and education status. This increased risk of externality also escalates the overall risks associated with reducing government legitimacy and weakening public institutions. Thereby, the relationship between globalization and the public sector is tremendously intricate and correlate with numerous variables and factors. In addition, low growth rate, economic crises, population aging, political uncertainty and emerging nationalism - as an interconnected set of issues - create a challenging outlook for the institutional arrangements to manage public sector entities in industrialized democracies (Bracci et al. 2015).

In the past two decades, nonetheless, developed countries have been unsuccessful to reduce the unfavorable effects of trade openness and rapid technological innovation, such as the decline in manufacturing jobs and widening income inequality. The "Great Recession" has exposed the underlying flaws of the "self-correcting" free market capitalism. According to Caldara et al. (2016), however, the latest financial crisis represents only one of the latest constituents in a long chain of exter- nal uncertainty shocks. Indeed, the public sector in developed capitalist democracies has recently been intermittently confronted with a series of complex external crises (Hodges and Lapsley 2016) - a banking crisis, a real economy crisis, a sovereign debt crisis, as well as a refugee and migration crisis. Comprehensive economic and financial crises of capitalism also frequently manifest themselves as political crises (Hernández \& Kriesi 2016), which can subsequently lead to the inability of governments to reinforce and continue their commitment to maintain government spending obligations over time (Frieden \& Walter 2017).

Furthermore, globalization has generated "trans-territorial flows and networks" (Pérez 2017) that immediately influence the functioning of political authority and power relations. In this interconnected and interdependent "world order", the global process of economic and financial exchanges significantly transforms the operation of the nation-state, the public sector, the procedures of political decision-making and modern political communities. Consequently, the emergence of global politics has progressively drawn into networks beyond time, space and the territorial nation-state. In this post-national context, the role of the public sector has shifted towards emphasizing a competition state, instead of reinforcing the development of interventionist government measures (Neilson \& Stubbs 2016).

In this context, this research intents to investigate the varying relationship and dynamics between globalized economic processes and the transformation of the public sector, as well as examines the inherent social implications and consequences of globalization. The research question posed for this study is as following, "how does the increasingly globalized economy influence the ongoing process of public sector change?" In order to answer the research question, this paper explores the socio-economic impacts of globalization, and the associated challenges, issues that the public sector encounters today, using a literature review and secondary data analysis methodology.

\section{THE CONCEPT OF GLOBALIZATION}

Globalization as an exceedingly multifaceted and controversial concept, expresses a complex process - in which, the world is transformed into a single, interconnected and interdependent global system. However, globalization also refers to a number of other phenomena, such as the "collapse" of time 
and space, the movement of people, technology, goods and capital, internationalization and economic liberalization. Thereby, defining globalization is spectacularly difficult, and the existing definitions of theoretical efforts are immensely contradictory concepts (Stiglitz 2017).

Bruff (2005) has distinguished three separable "waves" relevant to the impacts of globalization. According to the first two, globalization, as a predetermined force, has created an institutional framework that has forced nation-states to partially disappear or find new roles in an interdependent world. In contrast to the first two, the third wave is associated with an understanding of globalization as a discursive-political process, of which form is influenced not only by the material reality, but also by human or social constructs. The political activity within domestic political parties is considered as an important factor in managing the size of the public sector. However, in this theoretical sense, the policy-setting strength and mechanism of political actors are not unambiguously clear.

In economics, globalization refers to economic opportunities and internationalization - however, without adequate management controls, it also represents a perilous threat. The supporters and defenders of globalization - especially, politicians, bureaucrats and business elites - (á la "trickle down" theory) would argue that opening up the international market will eventually lead to prosperity for individuals and economic growth. The critics of globalization, in turn, highlight the adverse consequences of international market integration, such as the growth of inequalities between countries, social groups and people, and international market instability (Stiglitz 2017).

\section{The neoliberal aspect of globalization}

The so-called "neoliberal doctrine" has become indispensable to international development policy in the 1980s, when the enormous debt and financial crises of developing countries required the development of new solutions and ideas. With the introduction of the Washington Consensus, as a neoliberal manifesto, a growing criticism has been focused on emphasizing ownership, inclusiveness and partnership, in order to conduct self-directed structural changes in the context of interventionist development policy.

Predominantly, the neoliberal narrative of globalization is substantially determined and conditioned by an unlimited and unregulated free market economy perspective. According to Fairclough
(2006), this viewpoint has increasingly forced governments, as an active actor, to support, instead of compete and interfere with, market forces. Along these lines, the core aspects of neoliberalism are built on the advocation of economic freedom, self-regulating international markets, unobstructed competition between business organizations, unlimited mobility of goods, individuals and capital, tendering of services, and increased globalization, as well as deregulation, privatization and liberalization (Söderbaum 2008). In consonance with this ideological framework, individuals can succeed, as well as achieve economic and social security, and economic growth and profits are gradually accessible even for the disadvantaged groups.

This "compression" of space and time - the rapid transfer of data and capital between countries and business organizations - facilitates international trading activities based on real-time information, and is particularly necessary in technological development (Harvey 2007). Consequently, economic globalization, as an international dimension of neoliberalism, involves the opening up of trade and financial markets. Bhagwatin (2007), however, argues that these unscrupulous financial markets might threaten national economies, as they often involve incomplete information.

\section{THE CONTRADICTORY IMPACTS OF GLOBALIZATION}

The aforementioned principles of the Washington Consensus, such as trade liberalization, free movement of capital and workforce flexibility initially appears to be appropriate for most of the countries. On the other hand, the global economy may appear in different territories in significantly different ways. According to Rodrik (2014), the significantly distinctive features and financial capabilities of the countries have resulted in precarious economic, social and political conditions. He argues that there is a fundamental incompatibility between these processes of globalization, national sovereignty and democracy. Additionally, in the context of developing countries, neoliberal globalization is perpetuating inequalities and underdeveloped social systems. However, unselfconsciously, the extent of the inequality in the distribution of the benefits of trade liberalism is also affecting the economy and the social structure of developed countries. In such "political trilemma", "hyperglobalization", the nation-state and democracy could not possibly be maintained simultaneously. 
Rodrik (2011) also draws special attention to the economic catch-up of middle-income emerging economies, arguing that while China's economic growth continues to be strong, they seem to have stagnated over the last decade. Therefore, despite the principles of the Washington Consensus, there is no guarantee of economic convergence between countries. The reason behind the success of the middle-class of South Korea, Taiwan and China, is the excessive intervention of the government in the economy, rather than their increased openness to trade and capital flows.

Supplementary globalized trends, such as the growth of international trade, technological developments and the growth of the financial sector have contributed to revenue sharing. While these trends have supported, in particular, the growth of many emerging economies, they also have increased income disparities within and between countries. On the other hand, differences in fiscal policies and institutions also explain the differences between countries in terms of income inequalities. These progresses, especially technological developments, are expected to increase income disparities in both developed and developing countries. However, technology development raises demand for jobs requiring higher levels of expertise, at the expense of lower-level work. For example, skilled labor supply in the U.S. has increased since the early 1980 s, while the rapid development of technology has increased the demand for high-skilled labor. As a result, the rise in wages of high-skilled individuals might explain - at least some of - the growth in U.S. income disparities (Stiglitz 2017).

Milanović (2016), however, points out that the majority of citizens in the world have profited enormously from globalization and technological development. According to his results, even the income of the citizens of the less prosperous areas has increased in the last decade. At the same time, the lower middle-classes of the industrialized countries have remained unaffected - in both advantageous and disadvantageous directions - by globalized economic processes and structural changes. The importance of technological development is also supported by the IMF's analysis of the effects of global trends on income distribution (Jaumote et al. 2013). According to the analysis, technological development has the most significant impact on the growth of income disparities. In Milanović's (2016) view, with the increase in income disparities, globalized processes and technological development synergies are difficult to distinguish, since globalization has enabled a wider use of technology by gradually lowering its price. Increasingly wider use of technology has, in turn, increased wages for workers with higher levels of education.

According to the IMF (2014), global monetary and fiscal policies pursued by global institutions have had a significant impact on the distribution of the benefits of technology and globalization, and have played an important role in balancing income inequalities and distribution. As a result, intergovernmental direct taxation and fiscal transfers have reduced the income gap of developed countries by up to one-third. Milanović (2016) also concludes that the marginal tax rate of high-income categories has remained the same or has been reduced, and the tax rate on capital has generally declined since the 1980 s in many countries. However, this has contributed to the continuous increase in income disparities, and in those countries where income transfers have been increased, the impact of technological development and globalization on income distribution has disappeared. Merle (2013) expresses that the benefits of globalization and technological development, such as direct foreign investment, are unevenly distributed between countries, as well as between workers and enterprises.

Concerns about labor market competition, such as changes in demographic trends and slow growth in productivity, especially in the context of advanced economies, have intensified the (re)emergence of radical right-wing populist parties, as well as protectionist and defensive strategies. The shifts toward inward protectionism and the slowdown in international trade growth, as a result of anti-globalization policies, might further increase the growth challenges and issues.

For these aforementioned reasons, governments need to implement political interventions and programs that might facilitate adaptation to global changes, for example through taxation and income distribution policies, or by increasing access to education.

\section{THE CHALLENGES OF THE PUBLIC SECTOR}

The public sector has grown substantially in the last five decades in advanced capitalist democracies - at the same time, as the expansion of the public sector has been strong, the importance of foreign trade has also increased significantly. Globalization has created a "borderless" world, and the national market has been partially replaced by the global market, consisting of highly diverse nationalities, competitors and customers from all over the world. The public sector is immensely dependent on mar- 
ket conditions, the growth and stability of the economy, and on the level of employment. As a result of this change, the constant rigorous approaches surrounding the public sector have been pervaded by a strong sense of crisis (Arellano \& Bai 2017).

With the collapse of the housing bubble, austerity measures have been imposed on different areas of public spending (Hodges \& Lapsley 2016), including welfare and social security, education, and health care. In this regard, with the globalized economic environment, public debate often focuses on the constraints imposed by globalization on the public sector, the pressure from tax competition on public finances and the efficiency losses. Therefore, it is relevant to examine the impacts and factors of the relationship between globalization and the public sector.

\section{The Growth of the Public Sector}

In advanced capitalist democracies, the relationship between economic openness and the welfare state has been of interest since the 1970s. A myriad of concepts and theories - of both negative and positive correlations - have been presented, and a significant number of empirical studies have been carried out on the possible connection between transparency and the size of the public sector.

Three, contrasting hypotheses have emerged to explain the globalization-public sector nexus. The first, the efficiency hypothesis demonstrates that globalization reduces government sector size and governments' capacity to finance public spending. The second theory, in contrast, argues that globalization cannot be the explanation for the public sector crisis. Finally, the compensation hypothesis expresses that paradoxically, globalization induces a higher demand for social insurance which results in an extended public sector.

According to the efficiency hypothesis, economic globalization imposes constraints on public sector size, as capital is excessively mobile between geographical locations, and investors seek the most profitable investment opportunities across the globe. Tax financed public sector activities remarkably reduce the income of equity holders - thus, accelerate the depletion of capital assets. Along these lines, more-progressive taxation options, for instance, weaken the incentives for investment and human capital formation, and drive the capital out of the country, which eventually creates a need for external borrowing in the private sector (Peters 2012). Globalization, coupled with enabling interest-pursuing actors, also increases and tigh- tens competition between countries. For example, private sector and non-governmental organizations have been playing an increasingly important role in providing social and health insurance schemes. Privatization, as an economic and political strategy, has been primarily advocated as a means of reducing public expenditure and increasing efficiency. However, the risks associated with privatization have led to increased inequality or segregation, and, in addition, have decreased democratic accountability and control over public resources.

Those who emphasize changes in external economic conditions, demonstrate that changes in the public sector are generally attributable to the globalization phenomenon (Knutsen \& Rasmussen 2018). In particular, the economic dimension of globalization, alongside with increasing mobility of goods and capital, has been recognized as a main driving force behind these intervening processes. Likewise, increasing competition among nations for global market share and foreign direct investment has put pressure on governments to reduce production for businesses costs through deregulation and corporate tax cuts. According to this approach, the capacity of nation-states to pursue and deliver redistributive public policies has also been limited.

Furthermore, income transfers also largely distort labor market processes and intertemporal investment decisions (Hall \& O'Shea 2013). In addition, public consumption must be financed by taxation or loans, for which interest is paid by increased taxation in the long run. Public sector borrowing requires raising the interest rate, thus reduces investment. This also causes the exchange rate to rise, which further weakens the competitiveness of domestic producers. Thereby, in order to reduce efficiency losses and capital outflow pressures, the governments erode public spending and abolish progressive taxation.

Additionally, the tax burden on labor continues to decrease the global competitiveness of domestic companies, which in return reduces the public sector size and regulatory mechanisms. Thus, as a result of economic globalization, politicians can no longer use tax policy as a tool of social re-engineering as frequently as before, since raising taxes today would risk undermining the competitiveness of businesses, along with discouraging potential external investors (Hall \& O'Shea 2013). Apart from this, the economic and political role of the state, and thus its influence over shaping national public policy, has diminished as a result the uncertainties arising from the fundamental transformation of the global financial system. This has meant that 
governments have had to make certain changes in the tax system and public policy in order to advance the competitiveness of the national industry (Höllerer et al. 2017).

\section{EMPIRICAL EVIDENCES}

Similarly to Milanović's (2016) so-called "Elephant Chart", using World Bank (2018) data on global income distribution, our chart (Figure 1) depicts the development of global income during the decades of hyperglobalization, between 1980 and 2016 - although, it does not resemble an "elephant" anymore. During this period, world trade has grown unprecedentedly and substantially. The horizontal axis shows that the world's population has divided into separate income categories, where 0 means "the absolute losers of globalization" and 100 means "the biggest winners". The vertical axis shows the growth rate of real income. Figure 1 demonstrates a significant increase in the middle-class population of Asia, with the highest income growth (point A). The lower middle-class population of Europe indicates the absence of any growth in real income (point B). The "global plutocrats" represent the richest - particularly, the "global top 1 percent" -, whose real incomes have risen substantially between 1988 and 2016 (point C).

According to Milanović (2016), however, the middle-class of the world economy mainly belongs to the population of China, but also to the middle-class population of other Asian countries. The upper middle-class of the world economy primarily applies to the population of the oldest industrialized countries, especially the U.S., Germany and Japan. Approximately half of the top earners are from the U.S., and the other half belongs to Europe, Japan, Oceania and the rapidly emerging China.

Figure 1. Change in real income between 1980 and 2016 at various percentiles of global income distribution

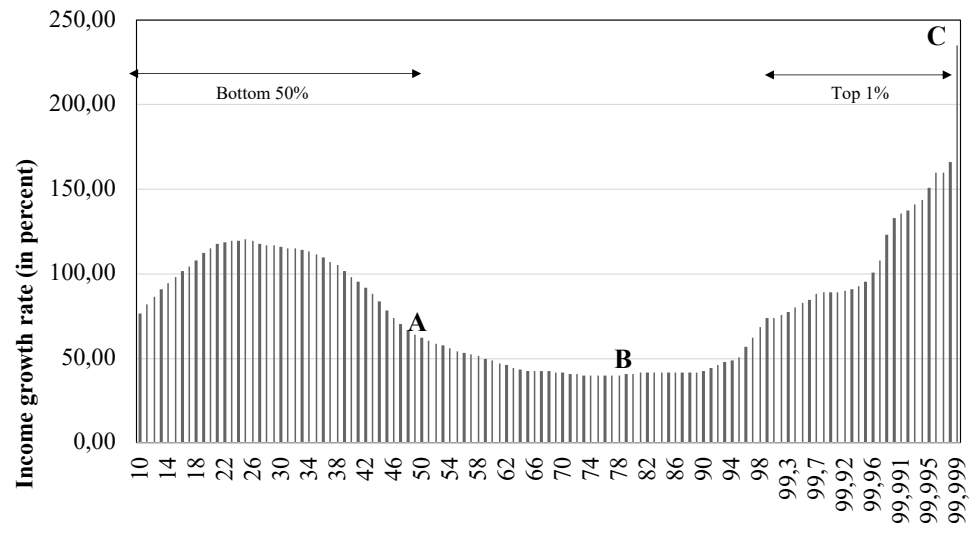

Percentile of global income distribution

Source: own construction

Figure 1, moreover, provides a startling description of global patterns of income inequality in the era of globalization. The income of middle-class in Asian countries has increased significantly, while the income gap in many advanced economies has drastically increased. There are also significant differences between the countries' development levels. For instance, in the U.S., the growth in income disparities has been stronger than in the United Kingdom, Germany and France. Although, hyperglobalization and the above-mentioned income development have taken place at the same time, this pattern cannot unambiguously explain the causal relationship between globalization and the growth in income differentials in developed countries and areas.

However, economic openness and public sector size have correlated positively with each other. Using OECD (2017) data, Figure 2 shows the average growth of the public sector expenditure in the 
OECD countries, including 35 OECD countries, from 1995 to 2016. The public sector expenditure has been measured as a share of the gross domestic product (GDP). Figure 2 demonstrates that the public sector has declined on average from the mid- 1990s up to the mid-2000s in the OECD countries, afterwards, the share of public expenditure in GPD has again picked up and reached the level of 1995 in 2009 , but it has started to decline remarkably after 2010

\section{Figure 2. The average growth of the public sector expenditure in the OECD countries}

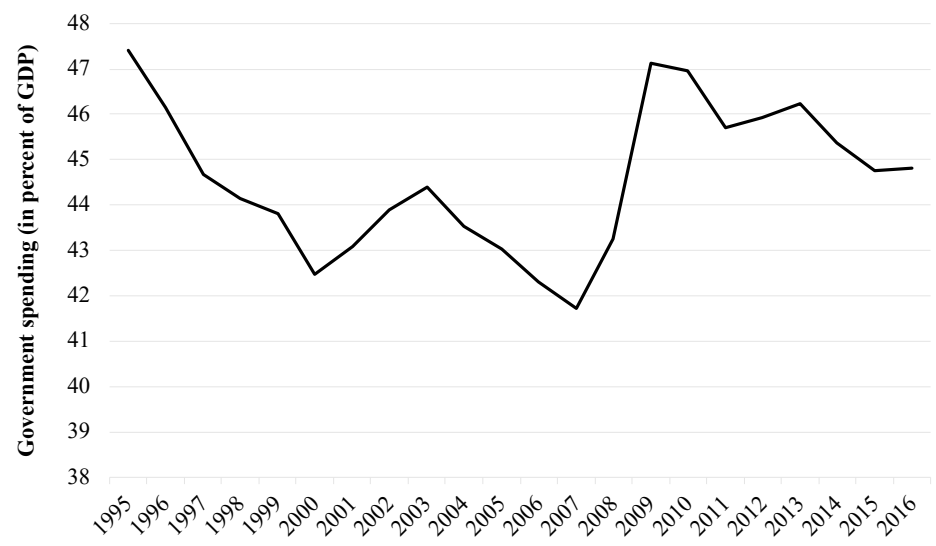

Source: own construction

On the other hand, Figure 3 reflects the growth of foreign trade's share in GDP based on data provided by the World Bank (2018) from 1995 to 2016. Foreign trade accounted for 43.5 percent of the world's GDP in 1995. It made progress until 2008 (60.8 percent), when the global economic crisis lead to a downturn. However, following 2009, the share has continued to rise, and foreign trade accounted for 60.5 percent of the world's GDP in 2011, but it has started to decline in recent years, falling to 56.4 percent in 2016 .

Figure 3. The growth of foreign trade's share in GDP, 1995-2016

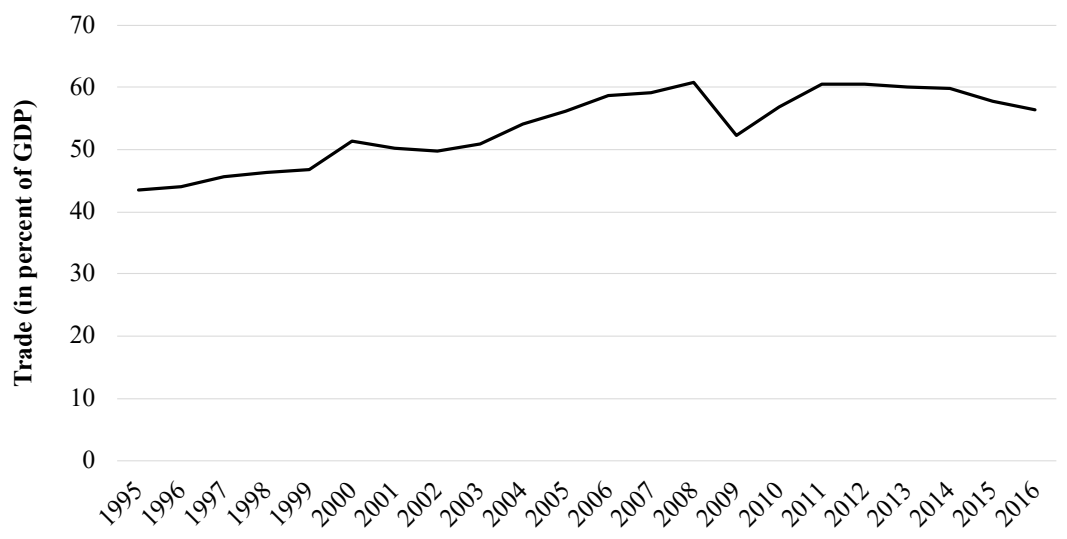

Source: own construction 
Figure 2 and Figure 3 also give a practical exhibition and explanation of the correlation between hyperglobalization and public sector size. In the OECD countries, size dispersion in the public sector is not great, yet a positive correlation between economic openness and the public sector size has been clearly found. Nonetheless, the correlation is a rather weak proof of the mechanism of transparency and the public sector size. Thus, the interpretation of the correlation may be influenced by many other factors, such as the size of nation-states. In small states, the public sector's share of GDP is higher - the smaller the state, the more it needs a coherent strategy to "survive". Small states with limited resources and influence rely more on economic openness, due to the fact they can't produce everything required domestically. Moreover, the historical and cultural factors underlying the economy of European countries and regions, such as the large extent of foreign trade and openness, also influence the size of the public sector.

\section{CONCLUSION AND RECOMMENDATIONS}

The economic turmoil of the past several years has placed developed capitalist democracies in a challenging situation. Under the pressure of globalized processes, nation-states have reduced their ability to control public sector expenditure. Additionally, the integration of financial markets across national borders has reduced the autonomy of national economic policy and led to the convergence of economic developments, the directions of monetary stability and budgetary equilibrium. Distinguishable institutional changes, including labor market liberalization, less progressive tax rates on income and deregulation in the finance sector, have also transformed the public sector.

This situation is due largely to the change in the international economic system, but also the different national socio-economic pressures for change, such as the aging population in advanced economies. Moreover, these factors can also be linked to the emergence of a post-industrial economy and a changing demographic structure (Huber and Stephens 2014)

Notwithstanding, when examining the impact of public sector expenditure on gross national income, however, for instance, the extent of the public sector does not have a statistically significant link to economic growth. Instead, it is apparent that slower economic growth involves a growth in public expenditure. Similarly, economic growth redu- ces the relative share of public spending on gross domestic product. Economic growth, therefore, affects public spending, but the opposite effect is not reflected in the statistics. Even if globalization increases the demand for public sector spending, it might simultaneously necessitate governments' capacity to carry out these demands, as the demands are not automatically met.

Paradoxically, the incentive effects of the public sector have created prosperous incentives for economy growth. However, the existing evidence across OECD countries at all stages of development does not suggest that these incentive effects are doubtlessly to be a dominant consideration in practice.

In response, countries have applied varying approaches to alleviate or prevent the consequences of these trends. Each socio-economic model has its own historical roots, societal values, economic pattern and national context. Globalization and the public sector - based on local context, and a multi-layered, multi-sectorial framework - should be rebalanced in an approach that works more efficient for more people and countries. Economic integration - in the form of financial globalization and regulatory harmonization - has overshot in certain areas and countries. Long-run economic efficiency requires a market-oriented economy, and extensive public sector schemes weaken the functioning of a market economy and consequently reduce the efficiency of the national economy. In this case, the traditional "welfare state" would be justified only by within-state altruism. 


\section{REFERENCES}

Arellano, C., and Bai, Y. (2017), "Fiscal austerity during debt crises", Economic Theory, 64 4, 657-73 https://doi.org/10.1007/s00199-0161008-x

Bhagwatin, J. (2007), In Defense of Globalization, New York: Oxford University Press. https://global.oup.com/academic/product/9780195330939

Bracci, E., Humphrey, C., Moll, J., and Steccolini, I. (2015), "Public sector accounting, accountability and austerity: More than balancing the books?", Accounting, Auditing \& Accountability Journal, 28 6, 878-908 https://doi.org/10.1108/ aaaj-06-2015-2090

Bruff, I. (2005), "Making Sense of the globalisation debate when engaging in political economy analysis", British Journal of Politics \& International Relations, 7 2, 261-80 https://doi. org/10.1111/j.1467-856x.2005.00177.x

Caldara, D., Fuentes-Albero, C., Gilchrist, S. and Zakrajšek, E. (2016), "The macroeconomic impact of financial and uncertainty shocks", European Economic Review, 88, 185-207 https://doi.org/10.1016/j.euroecorev.2016.02.020

Fairclough, N. (2006), Language and Globalization, London: Routledge https:/doi. org/10.4324/9780203593769

Frieden, J., and Walter, S. (2017), "Understanding the political economy of the Eurozone crisis", Annual Review of Political Science, 20 1, 371-90 https://doi.org/10.1146/annurevpolisci-051215-023101

Hall, S., and O’Shea, A. (2013), “Common-sense neoliberalism", Soundings, 55 55, 9-25 https:// doi.org/10.3898/136266213809450194

Harvey, D. (2007), A Brief History of Neoliberalism, Cambridge: Oxford University Press https://global.oup.com/academic/product/9780199283279

Hernández, E., and Kriesi, H. (2016), “The electoral consequences of the financial and economic crisis in Europe", European Journal of Political Research, 55 2, 203-24 https://doi. org/10.1111/1475-6765.12122

Hodges, R., and Lapsley, I. (2016), “A private sector failure, a public sector crisis - Reflections on the Great Recession", Financial Accountability \& Management, 32 3, 265-80 https://doi. org/10.1111/faam.12096

Höllerer, M. A., Walgenbach, P., and Drori, G. S. (2017), "The consequences of globalization for institutions and organizations", in: Greenwood, R., Oliver, C., Lawrence, T., and Meyer, R. E (eds.), The SAGE Handbook of Organizational Institutionalism, London: SAGE, 214-42 https://doi.org/10.4135/9781446280669.n9

Huber, E., and Stephens, J. D. (2014), "Income inequality and redistribution in post- industrial democracies: Demographic, economic and political determinants", Socio-Economic Review, 12 2, 245-67 https://doi.org/10.1093/ ser/mwu001

International Monetary Fund (2014), Fiscal Policy and Income Inequality, Retrieved: November 19, 2017 from http://www.imf.org/external/np/ pp/eng/2014/012314.pdf

Jaumotte, F., Lall, S., and Papageorgiou, C. (2013), "Rising income inequality: technology, or trade and financial globalization?", IMF Economic Review, 61 2, 271-309 https://doi.org/10.1057/ imfer.2013.7

Knutsen, C. H., and Rasmussen, M. (2018), "The autocratic welfare state: Old-age pensions, credible commitments, and regime survival", Comparative Political Studies, 51 5, 659-95 https:// doi.org/10.1177/0010414017710265

Merle, J-C. (2013), Spheres of Global Justice: Volume 1. Global Challenges to Liberal Democracy, Political Participation, Minorities and Migrations, London: Springer. https://doi. org/10.1007/978-94-007-5998-5

Milanović, B. (2016), Global Inequality: A New Approach for the Age of Globalization, Cambridge, MA: Belknap Press of Harvard University Press http://www.hup.harvard.edu/catalog. php?isbn=9780674737136

Neilson, D., and Stubbs, T. H. (2016), “Competition states in the neoliberal era: Towards third-generation regulation theory", Competition \& Change, 20 2, 122-44 https://doi. org/10.1177/1024529415623917

OECD (2017), OECD Data, Retrieved December 3, 2017 from https://data.oecd.org

Peters, J. (2012), "Neoliberal convergence in North America and Western Europe: Fiscal austerity, privatization, and public sector reform", Review of International Political Economy, 19 2, 208 35 https://doi.org/10.1080/09692290.2011.552 783

Pérez, G. P. (2017), "Nation state, political identities and the transformations of globalization", Open Journal of Social Sciences, 5 4, 9-30 https://doi.org/10.4236/jss.2017.54002

Rodrik, D. (2011), The Globalization Paradox: Democracy and the Future of the World Economy, New York: W. W. Norton \& Company 
https://drodrik.scholar.harvard.edu/publications/globalization-paradox-democracy-and-future-world-economy

Rodrik, D. (2014), "When ideas trump interests: Preferences, worldviews, and policy innovations", Journal of Economic Perspectives, 28 1, 189-208 https://doi.org/10.1257/jep.28.1.189

Seelkopf, L., Lierse, H., and Schmitt, C. (2016), "Trade liberalization and the global expansion of modern taxes", Review of International Political Economy, 23 2, 208-31 https://doi.org/10.1 080/09692290.2015.1125937
Söderbaum, P. (2008), Understanding Sustainability Economics: Towards Pluralism in Economics, London: Routledge. https://doi. org $/ 10.4324 / 9781849773638$

Stiglitz, J. E. (2017), "The overselling of globalization”, Business Economics, 52 3, 129-37 https:// doi.org/10.1057/s11369-017-0047-z

World Bank (2018), World Development Indicators, Retrieved: March 3, 2018 from http://databank.worldbank.org
Nándor Sári, PhD Student sari.nandor@yahoo.com University of Pécs Faculty of Humanities Interdisciplinary Doctoral School 